\title{
EXPERIMENTAL STUDIES ON PERFORMANCE OF STEEL FIBER AND POLYMER MODIFIED RECYCLED AGGREGATE CONCRETE
}

\author{
Prathik Kulkarni ${ }^{1}$, Kashimalla Ramesh ${ }^{2}$, N.M.Kanhe ${ }^{3}$, Dhanalakshmi Vasa ${ }^{4}$ \\ ${ }^{1}$ Assistant professor, Civil Engineering, Gurunanak Institute of Technical Campus, Telengana, India \\ ${ }^{2}$ Assistant professor, Civil Engineering, Gurunanak Institute of Technical Campus, Telengana, India \\ ${ }^{3}$ Professor, Civil Engineering, Principal,Gurunank Engineering College @ Nagpur, Maharastra, India \\ ${ }^{4}$ Assistant professor, Civil Engineering, Gurunanak Institute of Technical Campus, Telengana, India
}

\begin{abstract}
The amount of construction waste has been dramatically increased in the last decade due to increase of population \& high rise building in the country. So there is an immediate need of using the aggregate from the old demolished buildings for other construction works such as roads, canals, retaining walls ...etc.

Due to the lack of natural resource and dumping areas in the country, Recycling Aggregate is playing an important role in present situations. In this project a study on M25 Grade of concrete of Natural Aggregate(NA), Recycled Aggregate(RA), $30 \mathrm{Kg}$ $/ m^{3}$ Steel Fiber Recycled Aggregate(SFRA) (aspect ratio=50), Modified Polymer Recycled Aggregate(PMRA) (Styrene butadiene rubber polymer $=5 \%$ ) has been carried out with water cement ratio $=0.50$

In this experimental investigation total number of 12 cubes, 12 beams \& 12 cylinders of size 150x150mm, 150x150x700mm, 150x300mm specimens respectively were tested for 28 days \& 3 cubes of Natural Aggregate, 3 cubes of Recycled Aggregate , 3 cubes of Steel Fibre Recycled Aggregate, 3 cubes of Modified Polymer Recycled Aggregate were tested in compressive testing machine for 7 days. The project is carried out at Gurunanak engineering college, Nagpur
\end{abstract}

The following tests were carried out for the above specimens for 28 days

1) Compressive test 2) Split tensile test 3) Flexure test

Key words: na=natural aggregate1, ra=recycled aggregate2, sfra=steel fiber recycled aggregate3, pmra=polymer modified recycled aggregate4, conventional concrete (cc) 5, natural aggregate concrete (nac)6 with that of recycled aggregate concrete (rac7), steel fibre recycled aggregate concrete (sfrac8), polymer modified recycled aggregate concrete (pmrac)9.

$$
\text { - **** }
$$

\section{INTRODUCTION}

Concrete is a composite material composed of aggregate bonded together with a fluid cement which hardens over time. Any construction activity requires several materials such as concrete, steel, brick, stone, glass, clay, mud, wood, and so on

\section{Natural Aggregates:-}

Natural aggregates consist of rock fragments that are used in their natural state, or are used after mechanical processing such as crushing, washing, and sizing. Crushed stone and sand and gravel are the two primary sources of natural aggregate, which are used directly in construction or as a raw material for construction products such as concrete and bituminous road materials

\section{Recycled aggregate:-}

When structures made of concrete are demolished or renovated and the aggregate is taken from such buildings is know as recycled aggregate. The extensive research on recycled concrete aggregate and recycled aggregate concrete (RAC) as started from year 1945

\section{Indian Status:-}

Central Pollution Control Board(CPCD) has estimated current quantum of solid waste generation in India to the tune of $\mathbf{4 8}$ million tons per annum out of which, waste from construction industry only accounts for more than $\mathbf{2 5 \%}$. Management of such high quantum of waste puts enormous pressure on solid waste management system

\subsection{Benefits Of RA:-}

Reduce the amount of virgin rock mined. Decrease the energy used for processing. Conserve the energy used for trucking.

They are more cost efficient than most regular aggregates

\section{EXPERIMENTAL PROGRAM}

The general objectives of theses experimental investigation is to compare the Performance of conventional concrete (CC) or Natural Aggregate Concrete (NAC) with that of Recycled Aggregate Concrete (RAC), Steel Fibre Recycled Aggregate concrete (SFRAC), Polymer Modified Recycled Aggregate Concrete (PMRAC). 
The specific objective of the research work is to carry out comparative studies of NAC, RAC, SFRAC, and PMRAC. First of all physical and Mechanical Properties of NAC \& RAC were studied. Later on mix design were prepared using NAC \& RAC for Water/cement Ratio $=0.50$. Various tests like compressive test, split tensile test, Flexure test were carried out on these concrete.

The following mentioned physical and mechanical tests were carried out to compare NAC \& RAC.

\subsection{Physical Properties:-}

\begin{tabular}{|l|l|l|}
\hline Properties of aggregates & (NAC) & (RCA) \\
\hline Specific gravity & 2.70 & 2.42 \\
\hline Bulk density $(\mathrm{kg} / \mathrm{l})$ & 1.446 & 1.286 \\
\hline Flakiness Index $(\%)$ & 18 & 21 \\
\hline Elongation Index $(\%)$ & 0.8 & 2 \\
\hline Water absorption $(\%)$ & 0.70 & 2 \\
\hline
\end{tabular}

2.2 Mechanical Properties For Nac \& Rac:-

\begin{tabular}{|l|l|l|}
\hline Properties of aggregates & (NAC) & (RCA) \\
\hline Crushing strength (\%) & 8.205 & 11.785 \\
\hline Impact strength (\%) & 5 & 11.66 \\
\hline
\end{tabular}

\subsection{FINE AGGREGATE:-}

Fine aggregate used for medium and high strength concrete should be properly graded to give minimum void ratio and be free from deleterious materials like clay, silt content and chloride content. In present work fine aggregate was used locally available sand.

\begin{tabular}{|l|l|l|}
\hline SN.NO & TEST & RESULTS OBTAINED \\
\hline 1 & Specific Gravity & 2.6 \\
\hline 2 & Water absorption & 1.01 \\
\hline
\end{tabular}

\subsection{Cement:-}

Factors which are important in selection of type of cement are compressive strength at various ages, heat of hyderation, alkali content, $\mathrm{C}_{3} \mathrm{~A}$ content and compatibility with admixtures. Ordinary Portland cement (OPC) of 53 grades was used for preparing concrete throughout the concrete.

\begin{tabular}{|l|l|l|}
\hline Properties of aggregates & NAC & RAC \\
\hline Specific gravity of cement & 3.05 & 3.05 \\
\hline
\end{tabular}

\subsection{Mix Design}

Based on the Physical Properties of fine aggregate confirming to M25 grade of NAC using Indian standard recommended method of mix design .The mix was for NAC the same mix design were prepared for RAC, SFRAC, and PMRAC as to compare the various concrete properties of NAC with it. It was decided from past research work to use
$40 \mathrm{~kg} / \mathrm{m} 3$ steel fibre volume and SBR latex dosage in terms of polymer/cement ratio of $10 \%$ in RAC.

Mix design for medium strength concrete of grade M25 Mix design for M25 grade of concrete (NAC)

\section{I) Data for mix design:}

1) Characteristic strength $=25 \mathrm{MPA}$

2) Maximum size of aggregate $=20 \mathrm{~mm}$

3) Degree of workability (in terms of slump) $=50-100 \mathrm{~mm}$

4) Compaction factor $=0.85$

5) Degree of quality control=Good

6) Type of exposure=Mild

Specific Gravity of:

$\begin{array}{ll}\text { 1) Cement } & =3.05 \\ \text { 2) Coarse Aggregate } & =2.70 \\ \text { 3) Fine Aggregate } & =2.60\end{array}$

\section{II) Target mean strength of concrete:}

$$
\begin{aligned}
\text { Fck } & =f c k+(t * S) \\
& =25+1.65 * 4.0 \\
& =31.6 \mathrm{Mpa} .
\end{aligned}
$$

\section{III) Selection of water - cement ratio}

For target strength of $31.6 \mathrm{Mpa}$ and water cement ratio=0.50

\section{IV) Selection of water and sand content}

For $20 \mathrm{~mm}$ down grade aggregate and sand confirming to grading zone-II, water content per cubic metre of concrete $=186$ litres $/ \mathrm{m} 3$ and sand content as percentage of total aggregate by absolute volume $=35 \%$

For change in value in water ratio, compaction factor, for sand belonging to zone-III the following adjustment is required

Adjustment of sand, compaction factor

\begin{tabular}{|l|l|l|}
\hline \multirow{3}{*}{ Change in condition } & $\begin{array}{l}\text { Percent } \\
\text { Adjustment } \\
\text { Required }\end{array}$ \\
\cline { 2 - 3 } & $\begin{array}{l}\text { Water } \\
\text { content }\end{array}$ & $\begin{array}{l}\text { Sand in total } \\
\text { aggregate }\end{array}$ \\
\hline For sand confirming to Zone-II & 0 & 0 \\
of Table 4,IS 383-1970 & & \\
\hline For increase in compaction & $+1.5 \%$ & 0 \\
factor $(0.85-0.8)$, this is 0.05 & & \\
\hline For decrease in water cement & 0 & $-2 \%$ \\
ratio by $(0.60-0.50)=0.10$ & & $-2 \%$ \\
\hline Total & +1.5 & \\
\hline
\end{tabular}


Therefore, required sand content as percentage of total aggregate by

Absolute volume $=35-2=33 \%$

Required Water content $=186+2.79=188.79 \mathrm{lit} / \mathrm{m}^{3}$

V) Determination of cement content:

\begin{tabular}{|l|l|}
\hline Water/cement Ratio & $\mathbf{0 . 5 0}$ \\
\hline Water & $=188.79 \mathrm{lit} / \mathrm{m}^{3}$ \\
\hline Cement & $=188.79 / 0.50$ \\
\hline & \\
Cement & $\mathbf{3 7 7 . 5 8 ~ K g} / \mathbf{m}^{3}$ \\
\hline
\end{tabular}

\section{VI) Determination of coarse and fine aggregate:}

For nominal size of $20 \mathrm{~mm}$ aggregate, the air content is $2 \%$ taking into account and applying Following equation

For Fine Aggregate

$\mathrm{V}=\left[\mathrm{W}+\left(\mathrm{C} / \mathrm{S}_{\mathrm{c}}\right)+(1 / \mathrm{P}) *(\mathrm{fa} / \mathrm{SFa})\right] *(1 / 1000)$

$0.98 \mathrm{~m} 3=\left[188.79+(377.58 / 3.05)+(1 / 0.33) *\left(f_{a} / 2.6\right)\right] x$ $(1 / 1000)$

\section{$f_{a}=575.36 \mathrm{Kg} / \mathrm{m} 3$}

For Coarse Aggregate

$\mathrm{C}_{\mathrm{a}}=(1-\mathrm{P}) / \mathrm{P} * \mathrm{fa} * \mathrm{~S}_{\mathrm{c}} \mathrm{a} / \mathrm{Sfa}$

$\mathrm{C}_{\mathrm{a}}=(1-0.33) / 0.33 * 576.85 * 2.7 / 2.6$

$\mathrm{C}_{\mathrm{a}}=1213.08 \mathrm{Kg} / \mathrm{m} 3$

The mix proportion then becomes:-Mix proportion

\begin{tabular}{|l|l|l|l|}
\hline Water & Cement & FA & CA \\
\hline 188.79 & 377.58 & 575.36 & 1213.08 \\
\hline 0.50 & 1 & 1.523 & 3.21 \\
\hline
\end{tabular}

\begin{tabular}{|c|c|c|c|c|c|c|c|c|}
\hline 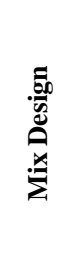 & 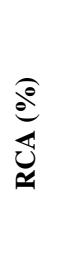 & 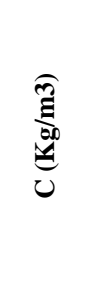 & 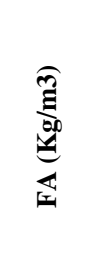 & 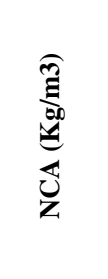 & 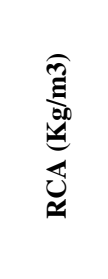 & 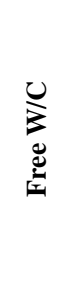 & 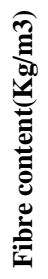 & 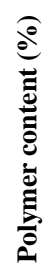 \\
\hline NA & 0 & 377.58 & 575.36 & 1213.08 & 0 & 0.50 & 0 & 0 \\
\hline RA & 100 & 377.58 & 575.36 & 0 & 1213.08 & 0.50 & 0 & 0 \\
\hline SFRA & 100 & 377.58 & 575.36 & 0 & 1213.08 & 0.5 & 30 & 0 \\
\hline SFRA & 100 & 377.58 & 575.36 & 0 & 1213.08 & 0.5 & 30 & 0 \\
\hline
\end{tabular}

\section{3) RESULTS AND DISCUSSIONS}

\section{1) Compressive strength for 7 days:-}

Compressive strength for 28 days is tested in CTM with different nature of concrete as tabulated below. The size of specimen is $150 \mathrm{~mm} \times 150 \mathrm{~mm}$.

Compressive strength of concrete $=$ load $(\mathrm{P}) /$ Area $(\mathrm{A})$

\begin{tabular}{|l|l|}
\hline Nature of concrete & Compressive strength (MPA) \\
\hline NAC & 18.2 \\
\hline RAC & 14 \\
\hline SFRAC & 17 \\
\hline PMRAC & 15.8 \\
\hline
\end{tabular}

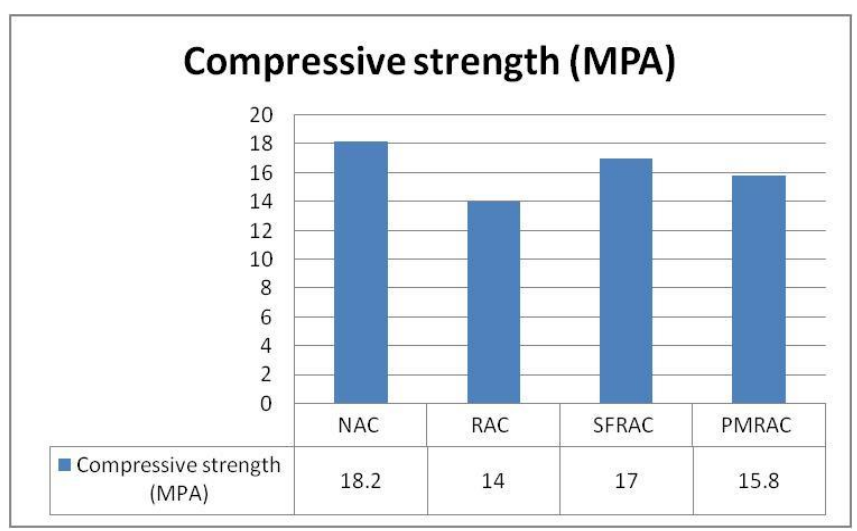

Compressive test was carried out for 7 days on cube of dimensions $150 \times 150 \times 150 \mathrm{~mm}$ and found that Natural Aggregate Concrete is having more compressive strength when compared with Recycle Aggregate Concrete and there is an increase of $21.4 \%$ with addition of Steel Fibres in Recycle Aggregate and a increase of $12.85 \%$ in Polymer Modified Recycled Aggregate Concrete

Out of these tests Specific Gravity is one of the important factors that needed to calculate mix design for concrete. The specific Gravity of aggregate is mainly affected by the amount of moister present and the geological properties of aggregate. In this project specific gravity of aggregate was used to determine the volume and weight of aggregate needed for concrete mixes. The determination of specific gravity is according to IS: $383-1970$
Cubes after testing

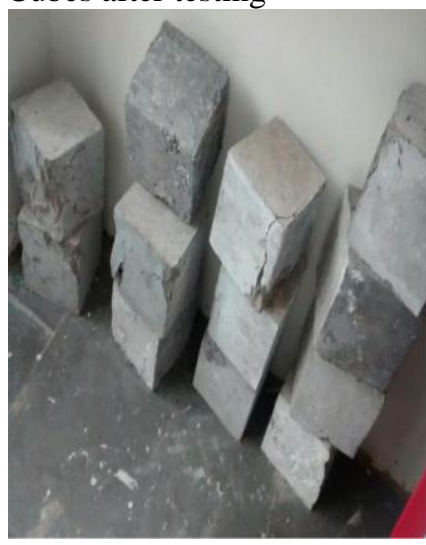

3.1.1) Compressive Strength of Concrete For 28
Compressive strength for 28 days is tested in CTM with different nature of concrete as tabulated below. The size of specimen is $150 \mathrm{~mm} \times 150 \mathrm{~m}$

Compressive strength of concrete $=\operatorname{load}(\mathrm{P}) / \operatorname{Area}(\mathrm{A})$ 


\begin{tabular}{|l|l|}
\hline Nature of concrete & Compressive strength (MPA) \\
\hline NAC & 31.23 \\
\hline RAC & 26.88 \\
\hline SFRAC & 32.73 \\
\hline PMRAC & 28.18 \\
\hline
\end{tabular}

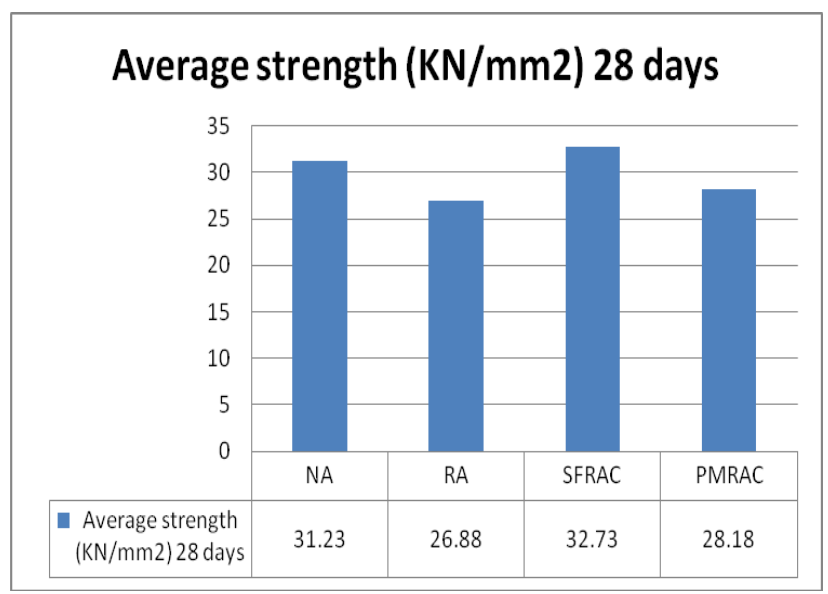

The above graphs tells that strength of steel fibre recycled aggregate concrete is more of all the concrete if we compare Natural aggregate concrete (NAC) with Recycled aggregate concrete(RAC) there is a decrease in strength of $16 \%$ but when we add fibres and polymer to Recycled aggregate concrete there is increase in strength by $21.76 \% \& 4.83 \%$ for Steel Fibre Recycled Aggregate Concrete(SFRAC) \& Polymer Modified Recycled aggregate Aggregate Concrete (PMRAC)

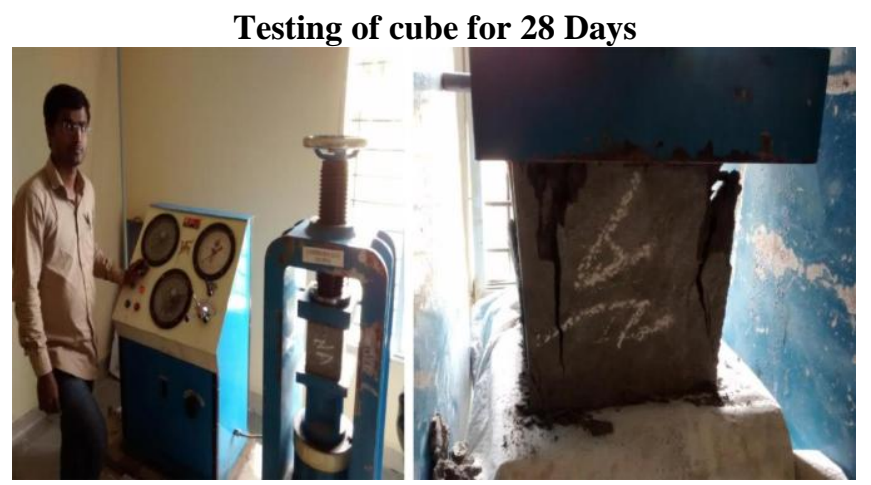

\section{2) Split Tensile test}

For tensile test the specimen of size $150 \mathrm{~mm} \times 300 \mathrm{~mm}$ is tested in CTM . The specimens were demoulded after $24 \mathrm{hrs}$ and was transferred to curing for 28 days.

Split tensile strength of concrete $=2 \mathrm{P} / \pi \mathrm{DL}$

\begin{tabular}{|l|l|}
\hline Nature of Aggregate & Average strength \\
\hline NAC & 3.74 \\
\hline RAC & 2.92 \\
\hline SFRAC & 3.83 \\
\hline PMRAC & 3.275 \\
\hline
\end{tabular}

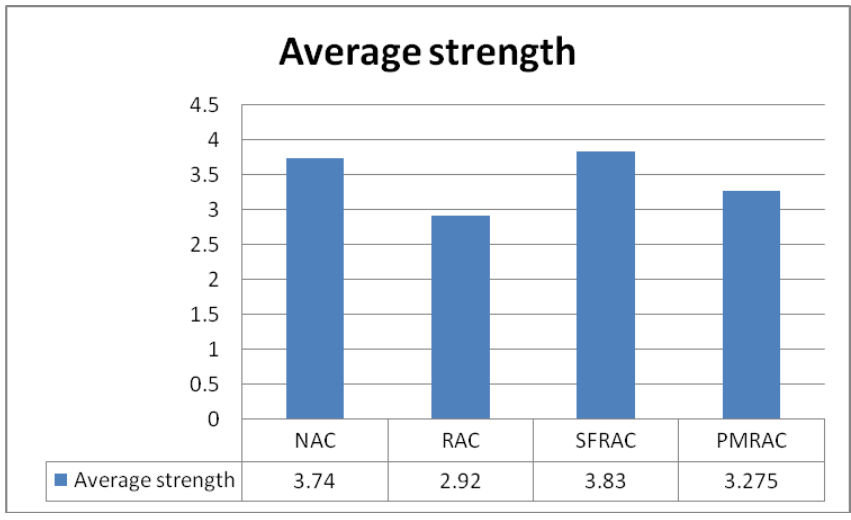

From the graph if we compare Natural Aggregate Concrete (NAC) with Recycled Aggregate Concrete (RAC) the strength of RAC is reduced by $28.0 \%$ so to increase the strength of RAC we have added Steel fiber of aspect ratio $(\mathrm{a} / \mathrm{d}=50)$ and polymer as $(\mathrm{ACSBR}=$ apple chemist styrene butadiene rubber) and there was an increase by $31.16 \%$ in SFRAC and $12.15 \%$ in PMRAC

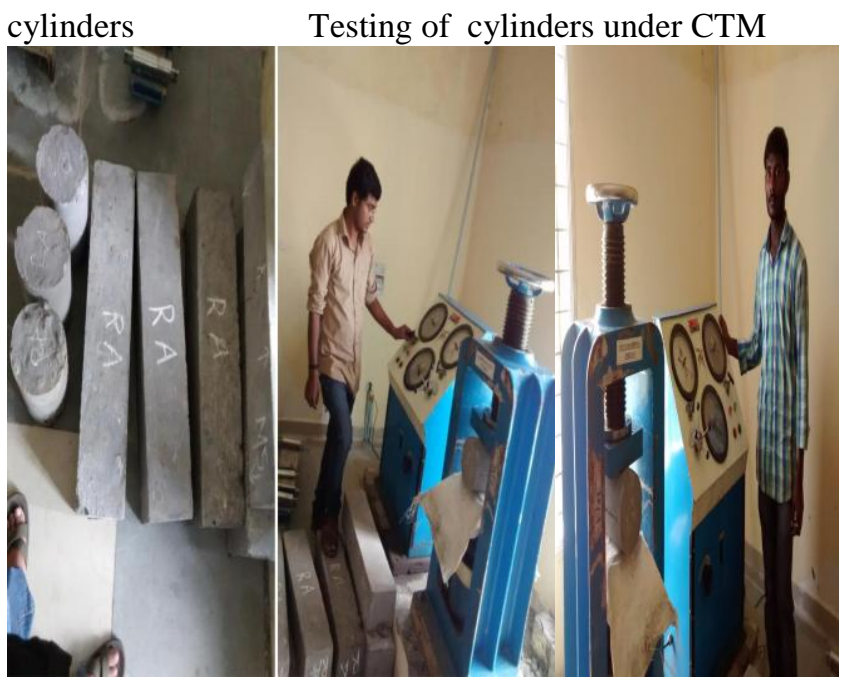

\section{3) Flexural test:-}

The flexural strength of the specimen is expressed as modulus of rupture which depends on the dimension of the beam and the type of loading. The size of specimen is 150x150x700mm and 3 point loading The modulus of rupture $\mathrm{fb}=\mathrm{PL} / \mathrm{bxd}^{2}$

\begin{tabular}{|l|l|}
\hline Nature of Aggregate & Average strength \\
\hline NAC & 6.9 \\
\hline RAC & 4.83 \\
\hline SFRAC & 7.73 \\
\hline PMRAC & 5.25 \\
\hline
\end{tabular}



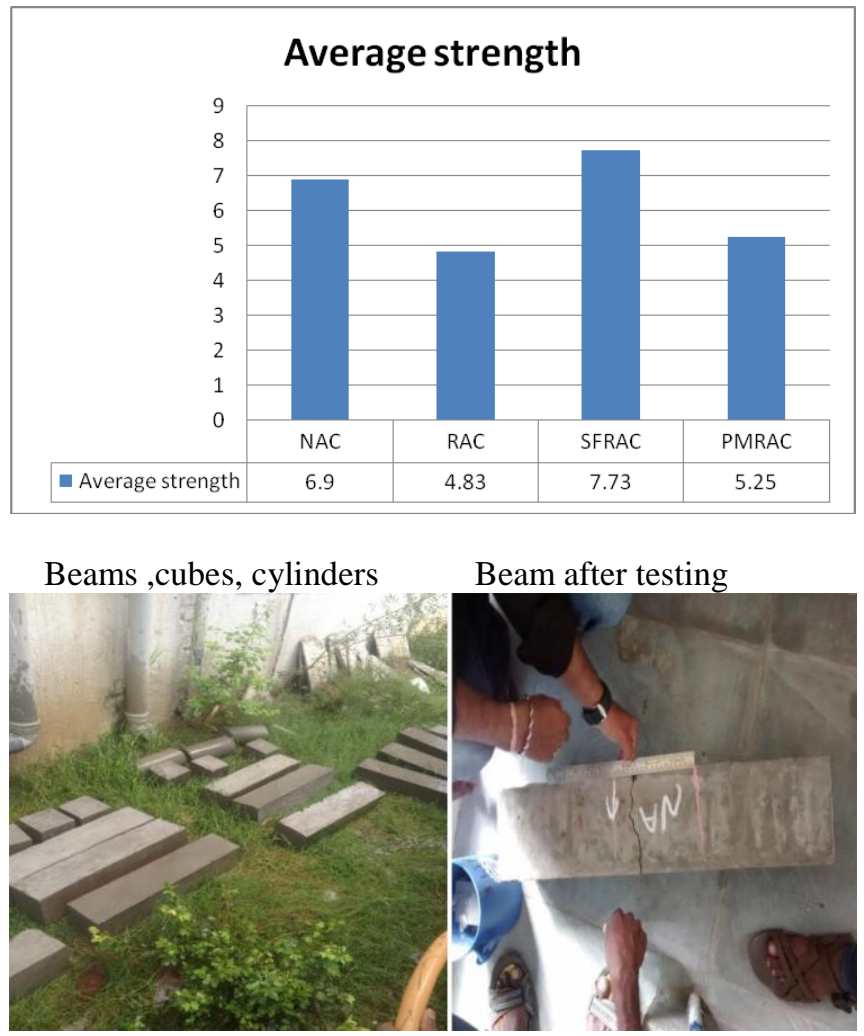

Recycled Aggregate Beam

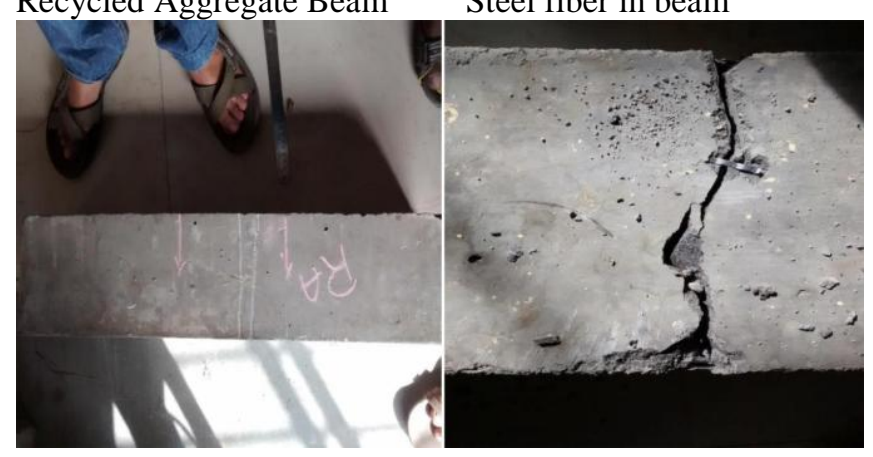

Consolidated Report:-

The report consist of all the 3 test i.e, compressive test, split tensile test and flexural test for 28 days and its graphical representation is given below with tabular column.

\begin{tabular}{|c|c|c|c|}
\hline $\begin{array}{l}\text { Nature } \\
\text { concrete }\end{array}$ & of $\begin{array}{l}\text { COMPRESSICE } \\
\text { STRENGTH }\end{array}$ & \begin{tabular}{|l} 
SPLIT \\
TENSILE \\
STRENGTH
\end{tabular} & $\begin{array}{l}\text { FLEXURAL } \\
\text { STRENGTH }\end{array}$ \\
\hline NAC & 31.23 & 3.74 & 6.9 \\
\hline RAC & 26.88 & 2.92 & 4.83 \\
\hline SFRAC & 32.73 & 3.83 & 7.73 \\
\hline PMRAC & 28.18 & 3.27 & 5.25 \\
\hline
\end{tabular}

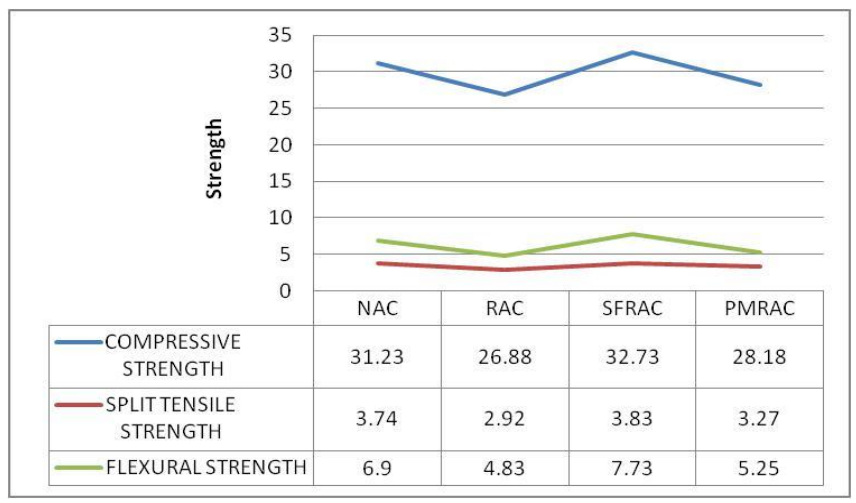

\section{CONCLUSIONS}

- It has been observed that the specific gravity of Natural Coarse Aggregate is more than the Recycled Coarse Aggregate

- Compressive test was carried out for 7 days on cube of dimensions 150x150x150mm and found that Natural Aggregate Concrete is having more compressive strength when compared with Recycle Aggregate Concrete and there is an increase of $21 \%$ with addition of Steel Fibres in Recycle Aggregate and a Decrease of $12 \%$ in Polymer Modified Recycled Aggregate Concrete.

- Compressive strength was carried out for 28 days for Natural aggregate concrete (NAC) Recycled aggregate concrete(RAC), Steel Fibre Recycled Aggregate Concrete(SFRAC) \& Polymer Modified Recycled aggregate Aggregate Concrete (PMRAC) and the strength of SFRAC is more when compared by NAC by $4.80 \%$ and there is a decrease in RAC by $16.18 \%$ so to improve the strength of RAC $30 \mathrm{~kg} / \mathrm{m}^{3}$ of Steel fiber and $5 \%$ of cement as polymer (Styrene Butadiene Rubber)was added and the strength was increased by $21.66 \%$ \& $4.83 \%$.

- $\quad$ Split tensile test was also carried out for 28 days and the strength of Recycled aggregate was less when compared to Natural aggregate concrete by $28 \%$ so to improve the strength we have added Steel fibres and polymer and there was an improvement in concrete by $31.16 \%$ for steel fiber and it was observed that SFRAC was having more strength then NAC but polymer modified recycled aggregate concrete has less strength compared to NAC by $14.37 \%$ but there is an increase when compared with RAC by $12.15 \%$

- $\quad$ Flexural test was carried out for 28 days under CTM with 3 point loading and it was observed that strength of recycled aggregate is very less when compared with NAC by $42.85 \%$ so to improve the strength RAC 30 $\mathrm{kg} / \mathrm{m}^{3}$ of Steel fiber and $5 \%$ of cement as polymer (Styrene Butadiene Rubber)was added and the strength was improved by $59.84 \%$ and $8.69 \%$ when compared with RAC.

- Overall view of the project was that the strength of Recycled Aggregate concrete was less when compared with Natural aggregate concrete and to improve the strength we have added $30 \mathrm{~kg} / \mathrm{m}^{3}$ of Steel fiber and $5 \%$ of cement as polymer (Styrene Butadiene Rubber). 


\section{REFERENCES}

[1]. Experimental Studies On Polymer Modified

[2]. Steel Fibre Reinforced Recycled Aggregate Concrete, IJAIEM, Volume 2, Issue 12, December 2013

[3]. Dr.G.D.Awchat1, Dr.N.M.Kanhe2

[4]. "RECYCLED COARSE AGGREGATES"

[5]. SUDHIRP.PATIL1,GANESHS.INGLE2,PRASHAN $\mathrm{T}$ D.SATHE3, International Journal Of Advanced Technology In Civil Engineering, ISSN: 2231 -5721, Volume-2, Issue-1, 2013

[6]. ISO 9001:2008 Certified

[7]. International Journal Of Engineering Science And Innovative Technology (IJESIT)

[8]. Volume 2, Issue 5, September 2013

[9]. IS-456-2000 Design Of Reinforced Concrete Structure

[10]. IS -10262 -2009 Concrete Mix Design

[11]. STRENGTH OF CONCRETE INCORPORATING AGGREGATES RECYCLED FROM DEMOLITION WASTE, R. Kumutha And K. Vijai, VOL. 5, NO. 5, MAY 2010 ISSN 1819-6608

[12]. ARPN Journal Of Engineering And Applied Science

\section{BIOGRAPHIES}

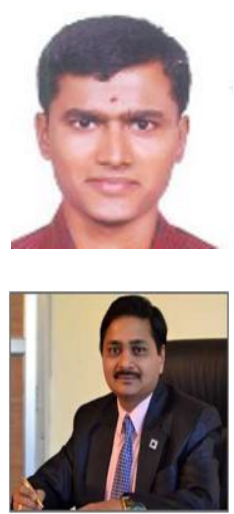

Prathik Kulkarni,

Assistant Professor,

GNITC,

Hyd

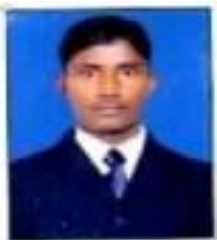

Dr. N.M.Kanhe,

Principal,

GNI,

Nagpur.

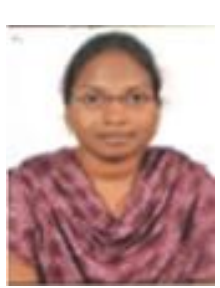

Dhanalakshmi Vasa,

Assistant Professor,

GNITC,

Hyd 